\title{
IMPLEMENTASI NILAI-NILAI LUHUR AJARAN KI HAJAR DEWANTARA DALAM PERKULIAHAN PENDIDIKAN PANCASILA UNTUK MENGEMBANGKAN KARAKTER MAHASISWA
}

\author{
Oleh : \\ Ronggo Warsito \\ Universitas Widya Dharma Klaten \\ e-mail: ronggo_warsito@unwidha.ac.id \\ Sahid Teguh Widodo \\ Universitas Sebelas Maret Surakarta \\ e-mail: sahidteguhwidodo@yahoo.com
}

\begin{abstract}
This research aims are 1) to describe the implementation of the noble values of Ki Hajar Dewantara's teaching to develop students' character, 2) to know the problems implementation of the noble values of Ki Hajar Dewantara's teaching to develop students' character, and 3) find the strategy was implemented of the noble values of Ki Hajar Dewantara's teaching to develop students' character. It used decriptive qualitative method with the single embedded case study strategy. The method data collection through in-depth interview, observation, documentation, and content analysis. Triangulation technique was used to check the validity. They were analyzed by using the interactive model. Conclusion: 1) the implementation of the noble values of Ki Hajar Dewantara's teaching very important to develop the students' character, 2) the problems implementation of the noble values of Ki Hajar Dewantara's teaching from internal dan external factors, and 3) the strategy was implemented of the noble values of Ki Hajar Dewantara's teaching to develop students' character with trilogi kepemimpinan.
\end{abstract}

Keywords: noble values of Ki Hajar Dewantara's teaching, students' character 
PENDAHULUAN

\section{A. Latar Belakang Masalah}

Pembangunan dan pengembangan karakter sangat dibutuhkan bagi pembangunan bangsa. Furqon Hidayatullah (2015: 31) menegaskan, "Mengapa pendidikan karakter itu penting dan mendesak bagi bangsa kita? Beliau memberi alasan karena bangsa kita telah lama memiliki kebiasaan-kebiasaan yang kurang kondusif untuk membangun bangsa yang unggul. Dari sisi perilaku, moralitas di kalangan pelajar semakin hari semakin jauh dari koridor etika maupun agama. Perkelahian, tawuran, intimidasi, dan perilaku negatif lainnya sudah menjadi perilaku yang tidak aneh lagi.

Pada awal tahun 1999, sebuah contoh kasus di Jakarta terjadi tawuran massal yang melibatkan ratusan pelajar dari berbagai sekolah. Aksi saling pukul berubah menjadi saling lempar batu. Tawuran yang semula terjadi di jalan raya, merengsek masuk ke kampung. Warga kampung yang terusik atas kehadiran pelajar yang sedang tawuran berusaha mengusirnya dan melempari para pelajar dengan batu. Sialnya, lemparan batu banyak yang sampai mengenai kampung sebelah. Merasa tersinggung karena tiba-tiba kampungnya dilempari batu, penduduk kampung sebelah pun membalasnya dengan melempar batu juga. Begitulah, sebuah tawuran yang semula terjadi antar pelajar menjadi tawuran antar kampung.
Membangun karakter bangsa merupakan kebutuhan mendasar dalam proses berbangsa dan bernegara. Muchlas Samani dan Haryanto (2012: 2) memberikan pernyataan tentang pentingnya pendidikan karakter dengan mengutip statemen dari The founding fathers. Para tokoh pendiri bangsa menyatakan: "Bangsa ini harus dibangun dengan mendahulukan pembangunan karakter (character building), karena dengan character building inilah akan membawa Indonesia menjadi bangsa yang besar, maju dan jaya, serta bermartabat. Kalau pembangunan karakter ini tidak dilakukan, maka Indonesia akan menjadi bangsa kuli."

Salah seorang pakar keTamansiswaan, Ki Supriyoko (2013: 1) dalam makalahnya yang berjudul Konsep Pendidikan Karakter Bangsa yang disajikan pada Seminar Nasional Memperingari Hari Pahlawan dan Hari Guru Bertemakan "Pendidikan Karakter Terpadu dalam Membangun Generasi Muda di Era Global" mengemukakan tentang pentingnya pendidikan karakter. Pentingnya pendidikan karakter terkait dengan kemunculannya dijelaskan bahwa pendidikan karakter bangsa bukan menjadi sesuatu yang baru bagi bangsa Indonesia. Para pendiri bangsa ini, sejak jauh hari sudah memikirkan pentingnya karakter untuk menjadikan bangsa ini menjadi besar dan terhormat di tengah-tengah masyarakat dunia. 
Upaya penanaman pendidikan karakter di sekolah, khususnya di sekolah menengah pertama dicoba dengan menciptakan sebuah pembelajaran dengan mengimplementasikan nilai-nilai luhur ajaran Ki Hajar Dewantara. Pentingnya pengimplementasian nilai-nilai luhur ajaran Ki Hajar Dewantara ini dilandasi dari beberapa realita dalam pembelajaran yang dilakukan di sekolah-sekolah maupun di perguruan tinggi. Di dunia pendidikan masih banyak dijumpai pembelajaran yang hanya bertumpu pada teori dan condong ke dimensi pengetahuan (cognitive oriented), cenderung intelektualitas serta mengabaikan pendidikan karakter.

Menurut Ki Hajar Dewantara (1962), penerapan pendidikan karakter dilakukan untuk membantu perkembangan hidup ke arah yang positif. Adapun pernyataannya adalah, "Pendidikan karakter diterapkan untuk menyokong perkembangan hidup anakanak. Perkembangan hidup ini diarahkan untuk menuju kepada satu sasaran positif yakni arah peradaban dalam sifatnya yang umum." Cara yang dapat dilakukan misalnya mengajarkan anak bagaimana duduk yang baik, hormat terhadap ibu bapak dan orang lain, suka menolong dan lain sebagainya.

Dalam bukunya yang berjudul Karya Ki Hajar Dewantara Bagian II A- Kebudajaan (1967), Ki Hajar Dewantara yang dikenal sebagai tokoh pendidikan berharap "anak-anak didik hendaknya diberikan anjuran-anjuran positif. Anjuran itu dimaksudkan agar anak terbiasa melakukan pelbagai laku yang baik dengan cara disengaja." Dengan begitu maka syarat pendidikan karakter yang dahulu biasa dikenal dengan istilah ngerti, ngerasa, dan ngelakoni ("tri-nga") dapat terpenuhi.

Cara penyajian pendidikan $\mathrm{Ki}$

Hajar Dewantara disebut metode among, yang menurut berlakunya dapat juga disebut metode tutwuri handayani, dalam rangka pelaksanaan sistem pendidikan (Ki Soeratman, 1980: 2). Penyebutan tutwuri handayani itu sudah dikandung di dalamnya suatu proses belajar mengajar tertentu dan memiliki ciri khas tersendiri. Dianutnya prinsip tutwuri handayani menuntut pula sebuah perwujudan dalam penyusunan kurikulum.

Ki Hajar Dewantara menghendaki dan mengharapkan pendidikan karakter yang terintegrasi dengan pengajaran pada setiap bidang studi. Dengan kata lain, Ki Hajar Dewantara menginginkan bahwa pada setiap pengajaran bidang studi apapun harus mengintegrasikannya dengan pendidikan karakter, dan tidak berhenti pada pengajaran mata pelajaran tersebut semata-mata. Harapan Ki Hajar Dewantara tersebut dikemukakan lagi oleh Ki Supriyoko dalam Harian Jawa Pos tanggal 15 Februari 2013 sebagai berikut. Ki Hajar Dewantara menyatakan budi pekerti wajib disampaikan kepada siswa. Pengajaran budi pekerti sebaiknya diberikan secara spontan oleh sekalian pamong; menurut adanya 
setiap kesempatan dan tidak harus menurut daftar pelajaran. Jadi, pendidikan budi pekerti harus diberikan oleh tiap-tiap guru/pamong, baik mengajarkan bahasa, sejarah, kebudayaan maupun ilmu alam, ilmu pasti, menggambar, dan sebagainya.

Model pembelajaran

Pendidikan Pancasila yang dilakukan di lembaga pendidikan, khususnya di perguruan tinggi, masih banyak menerapkan pembelajaran yang sangat terbatas pada penguasaan konseptual. Pembelajaran lebih banyak berorientasi pada hal-hal yang bersifat teoritik. Hasil belajar siswa lebih banyak didasarkan pada aspek pengetahuan dan keterampilan. Penilaian prestasi siswa mengesampingkan pendidikan nilai. Kondisi ini tidak sejalan dengan harapan bangsa Indonesia saat ini yang sedang mencanangkan pentingnya pendidikan karakter.

Terkait dengan pendidikan karakter, pada penelitian ini, para mahasiswa mendapat kesempatan untuk mengimplementasikan nilai-nilai luhur ajaran Ki Hajar Dewantara. Siswa akan merasakan dan mencintai kebajikan setelah mengkaji nilai-nilai luhur tersebut, selanjutnya akan berbuat kebaikan. Ini relevan dengan yang disampaikan oleh Suyanto (2010:1), bahwa "pendidikan karakter dilakukan secara holistik dan sistematik dengan menggunakan metode knowing the good, feeling loving the good, dan acting the good." Dengan pendidikan karakter yang mapan, setidaknya akan mengurangi munculnya tindak kekerasan.

Kekerasan yang senantiasa dibiarkan, apalagi "diamini", maka akan menjadi preseden buruk bagi kelangsungan hidup bangsa selanjutnya. Sebagai imbas dari ini semua, maka akibat buruk dari munculnya kekerasan tersebut akan menjalar ke seluruh kehidupan bangsa, termasuk dalam dunia pendidikan. Dan kenyataan sekarang, di dunia pendidikan sudah banyak bermunculan tindakan-tindakan yang mengarah pada fenomena kekerasan. As'aril Muhajir (2011: 34) menyatakan bahwa selain fenomena kekerasan, persoalan lain yang juga kian akrab dalam dunia pendidikan Indonesia adalah persoalan demoralisasi di kalangan pelajar. Dari sisi perilaku, moralitas di kalangan pelajar semakin hari semakin jauh dari koridor etika maupun agama. Perkelahian, tawuran, intimidasi, dan perilaku negatif lainnya sudah menjadi perilaku yang tidak aneh lagi.

Muchlas Samani dan Haryanto (2012: 2) menyebutkan bahwa kenakalan remaja biasa terjadi terutama di kota-kota besar, misalnya pemerasan/ kekerasan (bullying), kecenderungan dominasi senior terhadap yunior, penggunaan narkoba, dan lain-lain. Diakui atau tidak, terdapat kecenderungan bahwa perilaku pelajar sekarang kian bebas dan permisif. Hanya memang, penilaian harus dilakukan secara objektif, sebab kenyataannya memang tidak bisa dilakukan pembaharuan generasi secara 
sekilas. Namun demikian, walaupun hanya sebagian kecil saja yang perilakunya menyimpang (deviant behaviors), kondisinya membutuhkan perhatian dan penanganan secara tepat. Jika tidak, fenomena perilaku menyimpang, apalagi tindak kekerasan di kalangan pelajar akan semakin luas dan memprihatinkan.

Kecenderungan anak bangsa ke arah negatif sebagaimana disebutkan di atas sudah semakin nyata. Perkembangan kehidupan masyarakat masih ditandai dengan berbagai ketimpangan moral, akhlak, masalahmasalah sosial, ekonomi, politik, dan juga munculnya tindak kekerasan. Hal ini menunjukkan bahwa pendidikan di Indonesia belum mampu mengembangkan manusia dan masyarakat Indonesia sebagaimana yang diharapkan (Rokhman, Nurhadi, dan Muhsinatun, 2006: 116). Tidak sedikit generasi muda yang gagal menampilkan akhlak terpuji sesuai harapan orang tua. Kesopanan, sifatsifat ramah, tenggang rasa, rendah hati, suka menolong, solidaritas sosial dan sebagainya yang merupakan jati diri bangsa berabad-abad seolah-olah kurang begitu melekat kuat dalam diri insan Indonesia (Ki Supriyoko, 2003:3).

Salah satu resep atau obat yang perlu dicoba dan mendesak untuk segera dikonsumsi adalah menggali nilai-nilai karakter bangsa yang telah lama dilupakan dan untuk selanjutnya kita implementasikan dalam diri bangsa termasuk diri kita sebagai bagian dari bangsa Indonesia. Dalam penelitian ini akan digali nilai-nilai asli bangsa Indonesia yakni nilai-nilai luhur ajaran Ki Hajar Dewantara yang selanjutnya diimplementasikan dalam diri mahasiswa. Berangkat dari pemikiran di atas, maka disusun penelitian berjudul Implementasi Nilainilai Luhur Ajaran Ki Hajar Dewantara dalam Perkuliahan Pendidikan Pancasila untuk mengembangkan karakter mahasiswa.

\section{B. Rumusan Masalah}

Beberapa permasalahan yang dirumuskan dalam penelitian ini adalah sebagai berikut:

1. Mengapa perlu dilakukan implementasi nilai-nilai luhur ajaran Ki Hajar Dewantara dalam perkuliahan Pendidikan Pancasila?

2. Kendala-kendala apakah yang muncul pada pelaksanaan implementasi nilai-nilai luhur ajaran Ki Hajar Dewantara dalam perkuliahan Pendidikan Pancasila?

3. Bagaimanakah strategi implementasi nilai-nilai luhur ajaran Ki Hajar Dewantara dalam perkuliahan Pendidikan Pancasila untuk mengembangkan karakter mahasiswa?

\section{Tujuan Penelitian}

Tujuan yang hendak dicapai melalui penelitian ini dengan berdasarkan pada rumusan masalah sebagaimana tersebut di atas adalah untuk:

1. Mengetahui alasan-alasan mengapa perlu dilakukan implementasi nilai-nilai luhur 
ajaran Ki Hajar Dewantara dalam perkuliahan Pendidikan Pancasila.

2. Menemukan kendala-kendala yang muncul pada pelaksanaan implementasi nilai-nilai luhur ajaran Ki Hajar Dewantara dalam perkuliahan Pendidikan Pancasila.

3. Menemukan strategi pelaksanaan implementasi nilai-nilai luhur ajaran Ki Hajar Dewantara dalam perkuliahan Pendidikan Pancasila untuk mengembangkan karakter mahasiswa.

\section{KAJIAN TEORI}

\section{A. Nilai-nilai Luhur Ajaran Ki Hajar Dewantara}

Nilai-nilai luhur ajaran Ki Hajar Dewantara sebagaimana yang tersurat dalam karya-karyanya cukup beragam dan bersifat saling melengkapi. Nilainilai luhur yang dimaksud adalah sebagai berikut:

Nilai-nilai luhur yang pertama tentang ko-edukasi dan ko-instruksi atau mendidik dan mengajar anakanak perempuan dan laki-laki (Ki Hajar Dewantara, 1977: 6-9). Menurut adat Jawa, di dalam kehidupan keluarga antara anggota laki-laki dengan perempuan, meskipun dari satu keluarga juga ada adat kesopanan (tata krama). Dalam hal ini terlihatlah, bahwa bangsa kita mengindahkan kodratnya laki-laki dan perempuan.

Nilai-nilai luhur kedua adalah "konsepsi tentang momong, among, dan ngemong." Momong artinya mengasuh, membimbing dan menjaga supaya selamat berkembang dan tumbuh sesuai dengan harapan" (Purwadi, dkk., 2005: 319). Itulah yang dipakai sebagai dasar pendidikan sekarang. Pendidik akan selalu menjaga atas kelangsungan kehidupan batin sang anak, dan haruslah dijauhkan dari tiap-tiap paksaan. Namun demikian pendidik juga tidak akan "nguja" (membiarkan) anak-anak. Pendidik harus mengamat-amati, agar anak dapat tumbuh menurut kodrat.

Nilai-nilai luhur ajaran Ki Hajar Dewantara yang ketiga dinamakan “Alat Pendidikan." Yang dimaksud dengan alat pendidikan adalah usaha atau kegiatan untuk mencapai tujuan pendidikan. Alat pendidikan adalah alat-alat pokok, yakni cara-cara mendidik. Perlu diketahui bahwa caracara mendidik beragam banyaknya, akan tetapi pada dasarnya cara tersebut dapat dibagi menjadi enam model sebagaimana dikemukakan oleh $\mathrm{Ki}$ Hajar Dewantara (2009: 11) seperti berikut: (1) memberi contoh (voorbeeld), (2) pembiasaan(pakulinan, gewoontevorming), (3) pembelajaran (wulang-wuruk, leering), (4) perintah, paksaan, dan hukuman (regeering en tucht), (5) tindakan (laku, zelfbeheersching, zelfdiscipline), (6) pengalaman lahir dan batin (nglakoni, ngrasa, beleving/ngerti).

Azas Tri-kon merupakan nilainilai luhur ajaran Ki Hajar Dewantara yang keempat. "Azas Tri-kon" meliputi: (1) Kontinuitet, yang berarti bahwa garis hidup di zaman sekarang harus merupakan "lanjutan atau terusan" dari hidup di zaman yang 
silam; jangan "ulangan atau pun tiruan" hidup bangsa lain; (2) Konvergensi, dalam arti keharusan untuk hidup menyatu dan menghindari hidup menyendiri (isolasi) yang pada akhirnya menuju ke arah pertemuan hidup bangsa-bangsa lain sedunia; (3) Konsentrisitet, yang berarti bahwa sesudah "bersatu" dengan bangsabangsa lain sedunia, janganlah kehilangan "kepribadian" kita sendiri; sungguhpun sudah bertitik-pusat satu, namun di dalam lingkaran-lingkaran yang "konsentris" itu, tetap masih mempunyai sirkel sendiri.

Nilai-nilai luhur ajaran Ki Hajar Dewantara yang kelima adalah "Trihayu” (memayu hayuning sarira, memayu hayuning bangsa, memayu hayuning bawana). Maksud dari pernyataan ini adalah bahwa apa pun yang diperbuat oleh seseorang itu hendaknya dapat bermanfaat bagi dirinya sendiri, bermanfaat bagi bangsa, dan bermanfaat bagi manusia di seluruh dunia. Menurut $\mathrm{Ki}$ Supriyoko (2013: 4), memayu hayuning bawana disebut pula dengan memayu hayuning manungsa.

“Tri Sakti Jiwa (cipta, rasa, karsa)" merupakan nilai-nilai luhur ajaran Ki Hajar Dewantara yang keenam (Ki Hajar Dewantara, 1962: 451-452). Cipta adalah daya berpikir, yang bertugas mencari kebenaran sesuatu, dengan jalan membandingbandingkan keadaan yang satu dengan yang lain hingga dapat diketahui bedanya dan samanya atau mana yang benar dan yang salah. Rasa adalah segala gerak-gerik hati yang menyebabkan seseorang mau atau tidak mau, merasa senang atau susah, malu atau bangga, puas atau kecewa, berani atau takut, marah atau belas kasih, serta benci atau cinta. Karsa selalu timbul di samping dan seakan-akan sebagai hasil buah pikiran dan perasaan.

Dalam dunia modern seperti sekarang ini, konsep trisakti bisa diselaraskan dengan upaya memfasilitasi seluruh potensi anak didik dalam perkembangan belajarnya yang meliputi aspek kognitif, afektif, dan psikomotorik. Ketiga kesaktian tadi adalah syarat mutlak untuk mewujudkan manusia susila atau makhluk yang beradab. Ajaran hubungan antara cipta, rasa, dan karsa dijelaskan dalam satu tembang Macapat Asmaradana karya Ki Hajar Dewantara (1962: 359).

Trilogi Kepemimpinan yang meliputi Ing Ngarsa Sung Tuladha, Ing Madya Mangun Karsa, Tutwuri Handayani, merupakan nilai-nilai luhur ajaran Ki Hajar Dewantara yang ketujuh. Maksud dari trilogi tersebut adalah ketika berada di depan harus mampu menjadi teladan, ketika berada di tengah-tengah harus mampu membangun semangat, dan ketika berada di belakang harus mampu mendorong orang-orang dan pihakpihak yang dipimpinnya. Menurut Purwadi, dkk (2005: 192), Ing ngarsa sung tuladha maksudnya di depan memberi teladan. Seorang pemimpin ketika berada di depan hendaknya bisa menjadi teladan atau contoh; seorang 
pemimpin sebagai seorang yang terdepan dan terpandang senantiasa memberikan panutan-panutan yang baik sehingga dapat dijadikan suri teladan bagi masyarakatnya.

Bila diterapkan dalam dunia pendidikan, menjadi teladan merupakan bagian integral dari seorang guru, sehingga menjadi guru berarti menerima tanggung jawab untuk menjadi teladan." Terkait dengan hal ini, ungkapan yang sering dikemukakan adalah bahwa guru bisa digugu dan ditiru. Digugu maksudnya bahwa pesan-pesan yang disampaikan guru bisa dipercaya untuk dilaksanakan dan pola hidupnya bisa ditiru atau diteladani.

Menurut Sri Wintala Achmad (2013: 67), ing ngarsa sung tuladha mengandung makna bahwa "seorang pemimpin negara yang baik adalah yang selalu tampil di depan untuk memberikan teladan pada seluruh rakyatnya." Karenanya seorang pemimpin yang korupsi dan tindakantindakan tidak terpuji bakal dihujat oleh rakyatnya. Kewibawaannya sebagai pemimpin akan hancur berantakan.

Ing madya mangun karsa, maksudnya di tengah membangun kehendak. Seorang pemimpin ketika berada di tengah masyarakat, hendaknya bisa menjadi penyatu tujuan dan cita-cita masyarakat. Seorang pemimpin diantara yang dipimpin senantiasa berkonsolidasi memberikan bimbingan dan mengambil keputusan dengan musyawarah untuk mufakat dengan mengutamakan kepentingan masyarakat.

Dalam proses pembelajaran terutama dikaitkan dengan peran seorang guru atau pendidik, maka guru dalam hal ini berperan sebagai motivator, yakni memberikan motivasi atau dorongan kepada siswa sehingga para siswa tersebut mempunyai dorongan kuat untuk berswakarsa. Tutwuri handayani mengandung pengertian bahwa seorang pemimpin harus mengikuti pendapat atau tujuan yang telah disepakati bersama. Apabila terdapat suatu kendala yang menghambat tujuan tersebut, maka seorang pemimpin harus memberikan jalan keluar (solusi) melalui musyawarah mufakat. Dikaitkan dengan peran guru atau pendidik, dalam tutwuri handayani di sini, guru berperan sebagai fasilitator.

Nilai-nilai luhur ajaran Ki Hajar Dewantara yang kedelapan adalah Tripantang (harta, praja, wanita). Konsepsi Tripantang maksudnya dilarang menggunakan harta orang lain secara tidak benar (korupsi), menyalahgunakan jabatan (misal kolusi), dan bermain wanita (misal selingkuh). Ketiga pantangan ini hendaknya tidak dilanggar.

Nilai-nilai luhur yang kesembilan adalah Tritep, yakni tetep, antep, dan mantep. Ketetapan pikiran dan batin itulah yang akan menentukan kualitas seseorang. Dan jika tetep dan antep itu sudah ada, maka mantep itu datang juga, yakni tiada dapat 
diundurkan lagi (Ki Hajar Dewantara, 1962: 14).

Ngandel, kandel, kendel, dan bandel adalah nilai-nilai luhur ajaran Ki Hajar Dewantara yang kesepuluh. Ngandel artinya percaya akan pendirian yang teguh, maka kandel (berani) dan bandel (tidak lekas takut; tawakal) akan menyusul sendiri (Ki Hajar Dewantara, 1962: 14).

Nilai-nilai luhur yang kesebelas adalah neng, ning, nung, dan nang. Neng, ning, nung, maknanya kesucian pikiran dan batin yang didapat dengan ketenangan hati, itulah yang mendatangkan kekuatan. Dan kalau sudah ada tiga-tiganya itu, maka lahirlah nang, yakni kemenangan itu akan jadi bahagian insan manusia (Ki Hajar Dewantara, 1962: 14). Menurut Mochammad Tauchid (1963:56), neng, ning, nung, nang memiliki makna sebagai berikut. Dengan "neng”, yakni meneng, tenteram lahir batin, tidak nerveus, maka menjadi "ning", wening, bening, jernih pikiran kita, mudah membedakan mana hak, mana batil, mana benar dan salah; selanjutnya menjadi “nung”, hanung, kuat sentosa, kokoh lahir dan batin untuk mencapai cita-cita. Akhirnya "nang", menang, dan dapat wewenang, berhak dan kuasa atas usaha yang telah dilakukan.

Nilai-nilai luhur ajaran Ki Hajar Dewantara yang keduabelas adalah Pancadarma, sebagaimana dijelaskan oleh Tim Kreatif LKM UNYYogjakarta (2011: 78). Menurut Ki Hajar Dewantara, pendidikan adalah daya upaya untuk memajukan perkembangan budi pekerti (kekuatan batin), pikiran (intelek), dan jasmani anak-anak, selaras dengan alamnya dan masyarakatnya. Gagasan yang menarik dikaji dari Ki Hajar Dewantara adalah konsep Pancadarma Perguruan Tamansiswa. Konsep ini dikenal dengan nama "Asas-asas 1922." Melalui konsep ini, ingin diungkapkan bahwa usaha-usaha mencerdaskan kehidupan bangsa harus memiliki landasan yang kuat.

Nilai-nilai luhur ajaran Ki Hajar Dewantara yang sangat luas sebagaimana tersebut di atas, dalam penelitian ini difokuskan pada trilogi kepemimpinan. Menurut Hariwijaya (2013: 6) konsepsi trilogi kepemimpinan menurut $\mathrm{Ki}$ Hajar Dewantara diartikan bahwa " jika seorang pemimpin berada di depan, ia wajib memberi teladan, jika berada di tengah, harus mampu merumuskan tujuan dan cita-cita bersama, dan jika berada di belakang bertugas mendorong atau memberi motivasi."

Nilai-nilai luhur ajaran Ki Hajar Dewantara sebagaimana yang telah dipaparkan di atas, dikaitkan dengan lima karakter yang penulis pilih yakni empati, hati nurani, kontrol diri, rasa hormat, dan toleransi (Borba, M., 2001). Adapun kelima karakter tersebut dijelaskan sebagai berikut.

\section{Nilai-nilai Luhur yang Berkaitan dengan Empati}

Trilogi Kepemimpinan yang meliputi Ing Ngarsa Sung Tuladha, Ing Madya Mangun Karsa, Tutwuri 
Handayani, merupakan nilai-nilai luhur ajaran Ki Hajar Dewantara yang relevan dengan empati. Maksud dari trilogi tersebut adalah ketika berada di depan harus mampu menjadi teladan, ketika berada di tengah-tengah harus mampu membangun semangat, dan ketika berada di belakang harus mampu mendorong orang-orang dan pihakpihak yang dipimpinnya.

2. Nilai-nilai Luhur yang Berkaitan dengan Hati Nurani

"Tri Sakti Jiwa (cipta, rasa, karsa)" merupakan nilai-nilai luhur ajaran Ki Hajar Dewantara yang relevan dengan menumbuhkan hati nurani (Ki Hajar Dewantara, 1962: 451-452). Dalam dunia modern seperti sekarang ini, konsep trisakti bisa diselaraskan dengan upaya memfasilitasi seluruh potensi anak didik dalam perkembangan belajarnya yang meliputi aspek kognitif, afektif, dan psikomotorik. Ketiga kesaktian tadi adalah syarat mutlak untuk mewujudkan manusia susila atau makhluk yang beradab. Nilai-nilai luhur KHD lain yang terkait dengan hati nurani adalah neng, ning, nung, dan nang.

3. lai-nilai Luhur yang Berkaitan dengan Kontrol Diri

Nilai-nilai luhur ajaran Ki Hajar Dewantara yang berkaitan dengan kontrol diri adalah Tripantang (harta, praja, wanita). Konsepsi Tripantang maksudnya dilarang menggunakan harta orang lain secara tidak benar (korupsi), menyalahgunakan jabatan (misal kolusi), dan bermain wanita (misal selingkuh). Ketiga pantangan ini hendaknya tidak dilanggar.

\section{Nilai-nilai Luhur yang Berkaitan dengan Rasa Hormat}

Nilai-nilai luhur ajaran Ki Hajar Dewantara yang terkait dengan rasa hormat adalah tentang perhubungan antara anak laki-laki dan perempuan. Teristimewa anak-anak perempuan harus dididik rasa kesopanan (kesusilaan), karena keadaan dalam tingkah laku itulah "pagar keselamatan” (pagar rahayu). Anak perempuan yang kuat rasa kesopanannya, tidak akan mudah diganggu oleh orang laki-laki dan akan terlepas dari goda. Sebaliknya anak gadis yang membuang atau kurang kesopanannya, biasanya tidak ditakuti oleh orang laki-laki (dijamah) (Ki Hajar Dewantara, 1962: 8).

\section{Nilai-nilai Luhur yang Berkaitan dengan Toleransi}

Azas Tri-kon merupakan nilainilai luhur ajaran Ki Hajar Dewantara yang relevan dengan toleransi. Pendidikan menurut $\mathrm{Ki}$ Hajar Dewantara merupakan proses pembudayaan. Proses pembudayaan mengandung makna suatu usaha memberikan nilai-nilai luhur kepada generasi baru dalam masyarakat yang tidak hanya bersifat pemeliharaan tetapi juga dengan maksud memajukan serta mengembangkan kebudayaan menuju ke arah keluhuran budaya manusia. 
B. Pendidikan Karakter

1. Definisi dan Pentingnya Pendidikan Karakter

Menurut Ratna Megawangi (2004: 95), "pendidikan karakter adalah sebuah usaha untuk mendidik anak-anak agar dapat mengambil keputusan dengan bijak dan mempraktekkannya dalam kehidupan sehari-hari, sehingga dapat memberikan kontribusi yang positif kepada lingkungannya." Terkait dengan pentingnya pendidikan dalam kontribusinya terhadap lingkungannya, Mohamad Tarmizi Borhan dan Zurida Ismail dalam Malaysian Journal of Learning \& Instruction (2011: 117), terhadap temuannya menyatakan bahwa:

The low total mean score on the environmental knowledge component indicated the respondents' lack of knowledge on environmental issues especially in climate change. However, the respondents exhibited high positive environmental attitudes based on their responses to the responses to the relevant attitude items especially on items that related to adopting significant actions. Most of the items in the environmental behaviours component yielded considerably high mean scores which indicated a strong willingness on the part of the preservice teachers to take proenvironmental behaviours.

\section{Penjabaran Nilai dalam Pengembangan Karakter

Menurut Departemen

Pendidikan Nasional, ada 18 nilai-nilai dalam pengembangan pendidikan budaya dan karakter bangsa. Mulai tahun pelajaran 2011/2012, seluruh tingkat pendidikan di Indonesia harus menyisipkan pendidikan berkarakter tersebut dalam proses pendidikannya. Adapun nilai-nilai karakter yang dimaksud adalah sebagai berikut:

(1) religius, (2) jujur, (3) toleransi, (4) disiplin, (5) kerja keras, (6) kreatif, (7) mandiri, (8) demokratis, (9) rasa ingin tahu, (10) semangat kebangsaan, (11) cinta tanah air, (12) menghargai prestasi, (13) bersahabat/ komunikatif, (14) cinta damai, (15) gemar membaca, (16) peduli lingkungan, (17) peduli sosial, (18) tanggung jawab (Sumber: http://rumahinspirasi.com/ 18-nilaidalam-pendidikan-karakter-bangsa/).

Relevan dengan yang dikaji dalam penelitian ini, maka dari 18 nilai-nilai pendidikan karakter tersebut akan dikaitkan dengan nilai-nilai luhur ajaran Ki Hajar Dewantara yang menopang empati, hati nurani, kontrol diri, rasa hormat, dan toleransi. Setelah terjadinya pengaitan nilai-nilai pendidikan karakter berikutnya dituangkan dalam pembelajaran Pendidikan Pancasila dengan implementasi nilai-nilai luhur ajaran $\mathrm{Ki}$ Hajar Dewantara. 
3. Peranan Pendidikan Karakter bagi Pembangunan Bangsa

Umar Tirtarahardja (2005: 300), menyatakan bahwa "pendidikan menduduki posisi sentral dalam pembangunan karena sasarannya adalah peningkatan kualitas SDM", oleh sebab itu pendidikan juga merupakan alur tengah dari seluruh sektor pembangunan. Terdapat suatu kesan bahwa persepsi masyarakat umum tentang arti pembangunan lazimnya bersifat menjurus pada pembangunan fisik. Pembangunan semata-mata hanya beruang lingkup pembangunan material atau pembangunan fisik berupa pembangunan gedung, jembatan, pabrik, dan lain-lain. Padahal sukses tidaknya pembanguan fisik itu justru sangat ditentukan oleh keberhasilan pembangunan rohaniah/spiritual; yang secara bulat diartikan pembangunan manusia, dan ini menjadi tugas utama pendidikan.

Persepsi yang keliru tentang arti pembangunan yang menganggap bahwa pembangunan itu hanya sematamata pembangunan material dapat berdampak menghambat pembangunan sistem pendidikan, sebab yang benar pembangunan harus bersifat komprehensif. Persepsi yang mengatakan bahwa pembangunan diasosiasikan dengan pembangunan ekonomi dan industri, sementara pembangunan SDM tidak secara langsung terlihat, maka akan menimbulkan gejala penyerta yang negatif, antara lain kegoncangan sosial politik. Ini menunjukkan bahwa pembangunan dalam arti yang terbatas pada bidang ekonomi dan industri saja belum menggambarkan esensi pembangunan yang sebenarnya.

Saat proklamasi kemerdekaan Indonesia tanggal 17 Agustus 1945, para tokoh pendiri bangsa menyadari bahwa paling tidak ada tiga tantangan besar yang harus dihadapi. Pertama, adalah mendirikan negara yang bersatu dan berdaulat, kedua, adalah membangun bangsa, dan ketiga, membangun karakter. Ketiga tantangan tersebut secara jelas tampak dalam konsep negara bangsa (nation-state) dan pembangunan karakter bangsa (nation and character building).

Dari berbagai permasalahan dan kondisi yang sangat memprihatinkan tersebut, maka di sinilah letak pentingnya pendidikan budaya dan karakter bangsa. Pendidikan Pancasila sebagai salah satu program pendidikan karakter, melakukan pembelajaran yang secara programatik-prosedural berupaya memanusiakan (humanizing) dan membudayakan (civillizing) serta memberdayakan (empowering) manusia/ anak didik (diri dan kehidupannya) menjadi warga negara yang baik sebagaimana tuntutan keharusan/ yuridis konstitusional bangsa/ negara Indonesia. Warsito (2012: 23) dalam bukunya yang berjudul Pendidikan Pancasila Era Reformasi menyatakan bahwa "melalui Pendidikan Pancasila, Warga Negara Indonesia diharapkan mampu untuk memahami, menganalisis, dan 
menjawab masalah-masalah yang dihadapi oleh bangsanya secara berkesinambungan berdasarkan citacita dan tujuan bersama."

\section{Penelitian Relevan}

Artikel berjudul The

Pedagogical Value of Folk Literature as a Cultural Resource for Social Studies Instruction: An Analysis of Folktales from Denmark karya Virtue, David C; Vogler, Kenneth E. Journal of Social Studies Research 32.1 (Spring 2008): 28-39. Dari artikel tersebut diperoleh informasi bahwa Guru IPS termasuk di dalamnya Pendidikan Pancasila biasanya menggunakan cerita rakyat sebagai sumber informasi budaya di kelas untuk mereka gunakan sebagai cermin yang mencerminkan karakteristik kelompok budaya di mana mereka berasal. Adapun kesimpulannya adalah bahwa cerita rakyat adalah bentuk transmisi budaya yang bermanfaat.

Artikel dalam Jurnal

Internasional "Ethos" berjudul A Javanese Metropolis and Mental Life yang ditulis oleh Ferzacca, Steve,http://search.proquest.com/docvi ew/232928539/fultext. Diunduh pada hari Senin, 18 Maret 2013 Pukul 15.05 WIB. Inti dari isi jurnal yang relevan dengan kajian penulis adalah bahwa kehidupan orang Jawa senantiasa mengutamakan kehidupan sosial, serta kehidupan spiritual. Orang Jawa biasa melakukan kontemplasi atau perenungan. Sebagaimana telah diketahui bersama, bahwa Ki Hajar Dewantara adalah tokoh nasional
Bangsa Indonesia yang berasal dari Jawa pula, tepatnya dari Yogyakarta. Dengan melakukan suatu kajian, terlihat bahwa Ki Hajar Dewantara banyak memunculkan ide-ide atau gagasan yang ditulis dalam karyakaryanya yang cukup banyak. Karyakarya itu, jika disarikan sebagian besar berupa nilai-nilai luhur.

Marvin W. Berkowitz and Melinda C. Bier. (2007). What Works in Character Education. Hasil penelitian menjelaskan bahwa pendidikan karakter dapat bekerja dengan efektif ketika diimplementasikan dengan kesetiaan, keluasan dan memiliki dampak yang luas. Pendidikan karakter akan berjalan secara efektif jika dilakukan melalui pengembangan profesional, strategi pedagogis interaktif. Selain itu pendidikan karakter akan berjalan baik jika secara eksplisit fokus pada etika, pelatihan langsung terhadap pengembangan kompensasi sosial dan emosional, pemodelan karakter, menggunakan manajemen perilaku kelas yang sesuai dan melalui pengabdian kepada masyarakat. Saran yang ditawarkan untuk penelitian ke depan adalah praktek yang maksimal dan efektif dalam pendidikan karakter.

\section{METODE PENELITIAN}

\section{A. Strategi Penelitian}

Penelitian ini berbentuk studi eksploratif. Pada studi eksploratif ini, bentuk penelitian hakikatnya bersifat kualitatif. Cresswell dalam bukunya yang berjudul Research Design 
Qualitative \& Quantitative Approaches (1994: 147), menyatakan bahwa "qualitative research is interpretative research." Penelitian kualitatif merupakan penelitian interpretasi. Di dalam penelitian kualitatif, peneliti terlibat dalam pengalaman yang berkelanjutan dan terus-menerus dengan partisipan. Keterlibatan inilah yang nantinya memunculkan serangkaian isu-isu strategis, etis, dan personal dalam proses penelitian kualitatif.

Strategi penelitian yang digunakan dalam penelitian ini adalah tunggal terpancang. Tunggal maksudnya hanya ada satu masalah yang dikaji, yakni tentang implementasi nilai-nilai luhur ajaran Ki Hajar Dewantara dalam Perkuliahan Pendidikan Pancasila untuk mengembangkan karakter mahasiswa. Terpancang maksudnya ketika peneliti mengawali terjun ke lapangan untuk melakukan penelitian sudah memiliki banyak bekal dengan teori-teori yang relevan dengan pemecahan masalah dan fokus masalah sudah dirancang sebelum peneliti terjun di dalamnya.

\section{B. Tempat dan Waktu Penelitian}

Penelitian ini dilakukan di Universitas Widya Dharma Klaten. Selain itu, penelitian juga dilakukan di Museum Dewantara Kirti Griya Yogyakarta. Penelitian di museum ini dilaksanakan dengan melakukan observasi, dokumentasi, dan wawancara. Waktu penelitian dilaksanakan pada tahun akademik 2017/2018.

\section{Subjek Penelitian}

Subjek dalam penelitian ini adalah mahasiswa Universitas Widya Dharma Klaten tahun akademik 2017/2018. Selain para mahasiswa, subjek dalam penelitian ini juga melibatkan para dosen pengampu mata kuliah Pendidikan Pancasila. Untuk melengkapi data khususnya data kualitatif, subjek dalam penelitian ini melibatkan ketua dan pengelola Museum Dewantara Kirti Griya Yogyakarta yakni Nyi Sri Muryani dan Ki Agus Purwanto. Sebagai Key Informan dalam penelitian ini adalah Prof. Dr. H. Ki Supriyoko, S.D.U., M.Pd.

\section{Teknik Pengumpulan Data}

Penelitian berbentuk studi eksploratif dengan paradigma kualitatif ini, teknik pengumpulan data yang digunakan berupa wawancara mendalam (indepth interviewing), observasi atau pengamatan, dokumentasi, dan analisis isi.

Teknik dokumentasi salah satunya dilakukan di Museum Dewantara Kirti Griya Yogyakarta. Di museum ini, peneliti mendapatkan banyak sekali informasi yang jarang didapatkan di tempat lain, misalnya kumpulan surat Ki Hajar Dewantara (lebih dari 800 surat), buku-buku karya KHD, peninggalan-peninggalan $\mathrm{Ki}$ Hajar Dewantara dan telah diambil gambarnya oleh peneliti. Dalam hal ini berlaku prinsip snowball atau bola salju yang menggelinding, semakin lama semakin besar. 


\section{E. Teknik Pemeriksaan Keabsahan Data}

Pada penelitian kualitatif, pemeriksaan keabsahan data menggunakan teknik triangulasi (Patton, 1983: 331). Tashakkori dan Teddlie (2003: 14) menyatakan "the term triangulation does occur in each of the other six sparate "discipline" chapters noted previously, but primarily as a historical artifact rather than as a currently dominant term."Triangulasi yang digunakan adalah triangulasi data/sumber dan triangulasi metode. Triangulasi data adalah menguji keabsahan data dengan sumber yang berbeda, sedangkan triangulasi metode adalah dengan menguji data menggunakan metode yang berbeda. Menurut Tashakkori dan Teddlie (2010: 67), konsep "metode triangulasi” telah mendesak cendekiawan, yang pada akhirnya meruntuhkan hegemoni metodologis penganut metode tunggal.

Untuk triangulasi data atau sumber, dilakukan dengan mengkaji informasi dari nara sumber yang berbeda, yakni dari Ki Supriyoko (pakar ketamansiswaan dan nilai-nilai luhur ajaran Ki Hajar Dewantara), Nyi Sri Muryani dan Ki Agus Purwanto (Ketua dan Pengelola Museum Dewantara Kirti Griya Yogyakarta), perwakilan mahasiswa dan sebagainya. Triangulasi metode dilakukan dengan menggunakan beberapa metode pengumpulan data yang bervariasi seperti dengan wawancara mendalam, observasi, dan dokumentasi. Data yang telah dikroscek atau melalui proses triangulasi adalah data yang akurat, valid/sahih atau dapat dipercaya.

\section{F. Teknik Analisis Data}

Teknik analisis data yang digunakan adalah teknik analisis interaktif yakni berupa Components of Data Analysis: Interactive Model (Miles \& Huberman, 1984: 23) untuk data-data kualitatif. Model ini terdiri atas tiga komponen analisis yang saling terkait satu dengan yang lain secara simultan. Adapun ketiga komponen tersebut adalah (1) Data reduction (reduksi data), (2) Data display (penyajian data), dan (3) conclusions drawing/verification (penarikan kesimpulan/verifikasi).

Reduksi data, penyajian data, dan penarikan kesimpulan/verifikasi sebagai sesuatu yang jalin-menjalin. Hal ini terjadi pada saat sebelum, selama, dan sesudah pengumpulan data dalam bentuk yang sejajar, untuk membangun wawasan umum yang disebut "analisis." Hal ini relevan dengan yang disampaikan oleh Miles \& Huberman (1984: 21) sebagai berikut:

The data reduction/transforming process continues after fieldwork, until a final report is complete. Data Reduction is not something separate from analysis. It is part of analysis. The researcher's choices of which data chunks to code, which to pull out, which patterns summarize a number of chunks, what the evolving story is, are all analytic choices. 
Reduksi data merupakan proses yang kontinyu setelah terjun ke lapangan sampai pengumpulan data dirasa cukup. Reduksi data bukan sesuatu yang terpisah dari analisis secara keseluruhan. Model analisis interaktif dapat dilihat pada gambar di bawah ini.

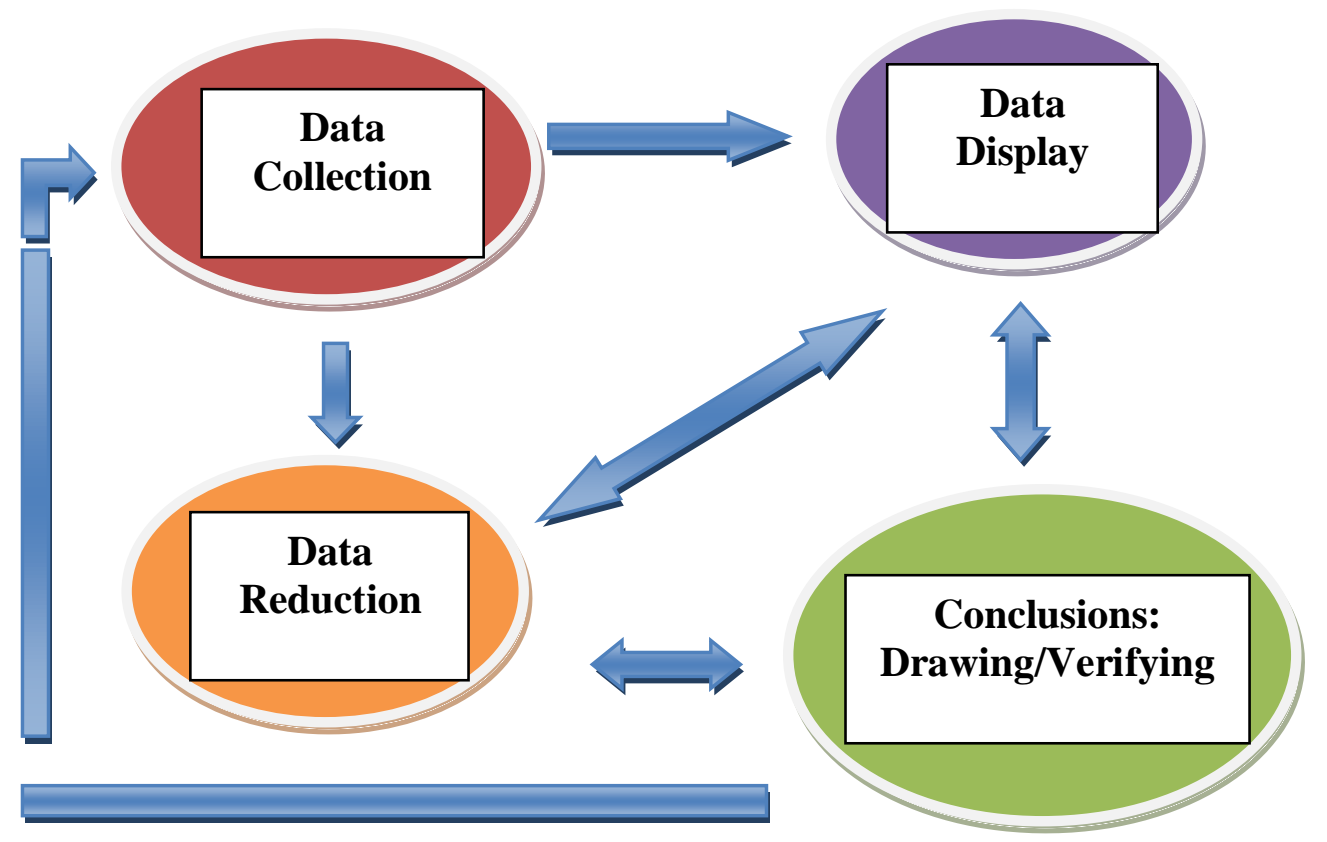

Gambar 1: Model Analisis Interaktif

Sumber: Component of Data Analysis : Interactive Model (Miles and Huberman, 1984: 23)

HASIL PENELITIAN DAN PEMBAHASAN

Dari hasil wawancara diperoleh tanggapan dari dosen dan mahasiswa tentang pentingnya pendidikan karakter. Mata kuliah Pendidikan Pancasila sudah mengajarkan pendidikan karakter. Sebagai bukti bahwa di dalam beberapa pokok bahasan terdapat pendidikan tentang mencintai sesama, mengajarkan bagaimana menjaga lingkungan dan mengajarkan bagaimana bergaul dalam masyarakat, agar terjalin hubungan yang harmonis antar sesama dan tidak saling menyakiti.

Dari bab I Pendidikan Pancasila salah satu bahasannya memaparkan tujuan Pendidikan Pancasila. Pendidikan Pancasila bertujuan menghasilkan peserta didik yang berperilaku, (1) memiliki kemampuan untuk mengambil sikap yang bertanggung jawab sesuai dengan hati nuraninya, (2) memiliki 
kemampuan untuk mengenali masalah hidup dan kesejahteraan serta cara-cara pemecahannya, (3) mengenali perubahan-perubahan dan perkembangan ilmu pengetahuan, teknologi, dan seni, serta (4) memiliki kemampuan untuk memaknai peristiwa sejarah dan nilai-nilai budaya bangsa untuk menggalang persatuan Indonesia (Kaelan, 2010: 15).

Pembahasan di atas relevan dengan artikel ilmiah berjudul Effectiveness of Social Science Learning Based on Noble Values of Ki Hajar Dewantara's Teaching to Strengthen the Students' Character oleh Warsito dan Asrowi dalam International Journal of Active Learning Vol. 2 (1) 2017, ISSN: 2528-505X. Dalam artikel ini disebutkan bahwa pendidikan karakter diawali dengan pengetahuan, kemudian perasaan atau sikap, dan akhirnya tindakan nyata.

Ada lima kecerdasan moral yang dikaji dan merupakan bagian dari pendidikan karakter yakni empati (empathy), hati nurani (conscience), kontrol diri (selfcontrol), rasa hormat (respectful), dan toleransi (tolerance). Lima karakter tersebut diimplementasikan dengan strategi trilogi kepemimpinan yang meliputi ing ngarsa sung tuladha, ing madya mangun karsa, tutwuri handayani. Pembelajaran IPS berbasis nilai-nilai luhur ajaran $\mathrm{Ki}$ Hajar Dewantara sangat efektif meningkatkan karakter siswa karena 1) nilai-nilai luhur ajaran $\mathrm{Ki}$ Hajar Dewantara adaptif dari nilai-nilai original bangsa Indonesia, 2) nilainilai luhur ajaran $\mathrm{Ki}$ Hajar Dewantara amat praktis, realistis, dan mudah dalam implementasi

Perkuliahan Pendidikan

Pancasila dengan implementasi nilainilai luhur ajaran $\mathrm{Ki}$ Hajar Dewantara mampu menutup kelemahan-kelemahan yang saat ini sering terjadi dan sebelumnya banyak dihiraukan, yakni pembelajaran yang hanya sampai pada aspek kognitif maupun psikomotor, sementara aspek afektif ditinggalkan. Hal ini sejalan dengan yang disampaikan oleh Goleman (2001) bahwa intellegence quotient saja belum cukup, tetapi harus dibarengi dengan emotional quotient dan spiritual quotient. Model perkuliahan Pendidikan Pancasila ini banyak membelajarkan para mahasiswa pada aspek afektif, dengan tidak meninggalkan aspek kognitif dan psikomotor.

\section{KESIMPULAN DAN SARAN}

Dalam perkuliahan Pendidikan Pancasila perlu dilakukan suatu perubahan paradigma, bukan hanya transfer of knowledge akan tetapi yang lebih penting adalah transfer of values. Hal ini berkaitan dengan dasar sebelumnya bahwa pembelajaran Pendidikan Pancasila sarat dengan nilai. Oleh karena itu para dosen perlu mengubah tradisi 
pembelajaran yang berorientasi pada hasil (by product) menjadi berorientasi pada proses berpikir kritis, rasional, dan proses penemuan nilai-nilai karakter dari materi pembelajaran (by process). Perkuliahan Pendidikan Pancasila harus mampu mengembangkan aspek pengetahuan, berpikir kritis dan rasional (kemampuan intelektual), mengembangkan aspek afektif (kemampuan personal yakni penghargaan dan rasa bangga terhadap pilihan nilai-nilai karakter), dan mengembangkan aspek skill/ keterampilan (kemampuan sosial yakni tindakan nyata sebagai aktualisasi diri dari nilai-nilai karakter). Kegiatan tersebut dilakukan dengan proses berpikir kritis dan rasional dalam interaksi sosialnya dengan kelompok diskusi. Dengan mengubah paradigma ini diharapkan perkuliahan Pendidikan Pancasila menjadi menarik, menantang, dan bermakna.

Pendidikan karakter diawali dari pengetahuan, kemudian ke perasaan atau sikap dan akhirnya ke tindakan nyata/perilaku. Dengan kata lain, pendidikan karakter berawal dari knowing the good, kemudian ditumbuhkan menjadi feeling the good, dan akhirnya menjadi acting the good. Dengan demikian akan terjadi proses implementasi dan internalisasi nilai-nilai karakter secara berkelanjutan dalam konteks lingkungan sosialnya. Budaya ini akan terinternalisasi dalam kepribadian peserta didik yang pada gilirannya akan mempengaruhi perilakunya. Lebih lanjut diharapkan melalui perkuliahan Pendidikan Pancasila, para mahasiswa akan menjadi manusia yang berkarakter dan cerdas. Beberapa hal yang menjadi temuan dalam penelitian ini dapat digunakan sebagai masukan oleh beberapa pihak. Beberapa pihak yang dimaksud adalah:

1. Dosen Pengampu Pendidikan Pancasila

Dosen adalah pelaksana terdepan dari kurikulum dan pembelajaran. Para dosen dapat menggunakan hasil penelitian ini untuk meningkatkan proses dan hasil pembelajaran. Dosen Pendidikan Pancasila dapat menggunakan model perkuliahan dengan mengimplementasikan nilainilai luhur ajaran $\mathrm{Ki}$ Hajar Dewantara. Dalam proses pembelajaran, sedapat mungkin para dosen Pendidikan Pancasila mengaplikasikan dan mengembangkan pendidikan karakter.

2. Koordinator/Penanggung Jawab MKU Pendidikan Pancasila Koordinator MKU adalah pengelola dan sekaligus penanggung jawab pelaksanaan MKU di perguruan tinggi. Inovasi dan upaya-upaya peningkatan mutu pendidikan/ pembelajaran yang dilakukan para dosen, harus diarahkan, didorong, dibantu dan difasilitasi oleh koordinator MKU. Untuk membantu memfasilitasi inovasi yang dilakukan guru, para koordinator terlebih 
19 Ronggo Warsito \& Sahid Teguh : implementasi nilai-nilai luhur ajaran ...

dahulu harus memahami perkuliahan

Pendidikan Pancasila dengan

implementasi nilai-nilai luhur ajaran

Ki Hajar Dewantara untuk

mengembangkan karakter

mahasiswa.

3. Untuk peneliti selanjutnya

Fokus penelitian ini adalah pengembangan karakter mahasiswa dengan implementasi nilai-nilai luhur ajaran Ki Hajar Dewantara. Para peneliti lain dapat melakukan kajian sejenis dengan fokus pembahasan yang berbeda misalnya pengembangan karakter dilakukan dengan strategi yang berbeda. 


\section{DAFTAR PUSTAKA}

As'aril Muhajir. (2011). Ilmu pendidikan perspektif kontekstual. Yogyakarta: ArRuzz Media.

Berkowitz, Marvin W. and Melinda C. Bier. 2007. What works in character education, Journal of Research in Character Education, 5(1), 2007, pp. $29-48$.

Borba, M. (2001). Building moral intelligence.(Membangun kecerdasan moral). Alih bahasa: Lina Jusuf. Jakarta: PT Gramedia Pustaka Utama.

Creswell, J.W. (1994). Research design quantitative approaches. California, London, New Delhi: Sage Publications.

Departemen Pendidikan Nasional. (2008). Materi pelatihan kurikulum satuan pendidikan (KTSP). Jakarta: Dirjen Dikdasmen.

Ferzacca, S. (2002). A Javanese metropolis and mental life. Ethos. 301/2. Source: http://search.proquest.com/docview. Diunduh: Senin, 18 Maret 2013 pukul 15.05 WIB.

Furqon Hidayatullah, M. (2015). Mendidik Karakter: Tugas Mulia Pendidik. Solo: Cakra Wijaya.

Goleman, D. (2001). Emotional intellegence (kecerdasan emosional). Jakarta: Gramedia Pustaka Utama.

Hariwijaya, M. (2013). Semiotika Jawa: Kajian Makna Falsafah Tradisi. Yogyakarta: Paradigma Indonesia.

Kaelan. (2010). Pendidikan Pancasila SK Dirjen Dikti No. 38/DIKTI/KEP/2002. Yogyakarta: Paradigma.

Ki Hadjar Dewantara. (1962). Karja Ki Hadjar Dewantara. Jogjakarta: Madjelis Luhur Persatuan Taman Siswa.

. (1967). Karja Ki Hadjar Dewantara Bagian IIA: Kebudajaan. Jogjakarta: Madjelis Luhur Persatuan Taman Siswa.

. (1977). Karya Ki Hadjar Dewantara Bagian Pertama: Pendidikan. Yogyakarta: Majelis Luhur Persatuan Taman Siswa. . (2009). Menuju Manusia Merdeka. Yogyakarta: Leutika.

Ki Soeratman. (1980). Tutwuri Handayani. Yogyakarta: Majelis Luhur Tamansiswa.

Ki Supriyoko. (2003). Menuju Masyarakat Tertib Damai Salam Bahagia sebagai Karakter Bangsa Masa Depan.Makalah. Disampaikan dalam Forum Sarasehan Kebudayaan. Yogyakarta, 19-20 Mei 2003. 
. (2013). Budi Pekerti Masuk Perdais. 27 Februari 2013. Kedaulatan

Rakyat, p. 2

(2013). Konsep Pendidikan Karakter Bangsa: Pendidikan Karakter

Terpadu dalam Membangun Generasi Muda di Era Global. Makalah.

Disampaikan dalam Forum Seminar Nasional Memperingari Hari

Pahlawan dan Hari Guru di Semarang, 30 November 2013.

. (2013). Makrifat Budi Pekerti Ki Hajar.15 Februari 2013. Jawa Pos.

. (2013). Mengkaji Filsafat Pendidikan Ki Hajar Dewantara. Makalah.

Dipresentasikan dalam Forum Lokakarya "Implementasi Pemikiran KHD dalam Pembelajaran di Perguruan Tinggi" Diselenggarakan oleh Pusat Pengembangan Pendidikan UGM Yogyakarta di Hotel Santika Yogyakarta, 16 November 2013.

Miles, M. B. \& Huberman, A. M. (1984). Qualitative Data Analysis, A Sourcebook of New Methods. Beverly Hills, London: Sage Publications.

Mochammad Tauchid. (1963). Perjuangan dan Ajaran Hidup Ki Hajar Dewantara. Yogyakarta: Majelis Luhur Tamansiswa.

Mohamad Termizi Borhan \& Zurida Ismail. (2011). Pre-Service Teachers' Perception Toward Environmental Knowledge, Attitudes and Behaviours. Malaysian Journal of Learning \& Instruction mjli.Vol. 8 (2011) : 117-137.

Muchlas Samani dan Haryanto. (2012). Konsep dan Model Pendidikan Karakter. Bandung: PT Remaja Rosdakarya.

Nur M. Rokhman, Nurhadi, \& Muhsinatun S. (2006). "Pengembangan Kurikulum Pengetahuan Sosial Terpadu secara Tematik di Tingkat SLTP: Sebuah Pemikiran Awal." ISTORIA. Jurnal Pendidikan dan Ilmu Sejarah.Vol. 1 No. 2, Maret 2006. Yogyakarta: FISE.

Patton, M.Q. (1983). Qualitative Evaluations Methods. London: Sage Publication.

Purwadi, dkk. (2005). Ensiklopedi Kebudayaan Jawa. Yogyakarta: Bina Media.

Ratna Megawangi. (2004). Pendidikan Karakter; Solusi yang Tepat untuk Membangun Bangsa. Bogor: Indonesia Heritage Foundation.

Sri Wintala Achmad. (2013). Falsafah Kepemimpinan Jawa-Soeharto, Sri Sultan HB IX, dan Jokowi. Yogyakarta: Penerbit Araska.

Suyanto. (2010). Urgensi Pendidikan Karakter.http://www.mendikdasmen. depdiknas.go.id/web/pages/urgensi.html, diunduh 17-1-2014.

Tashakkori, A. \& Teddlie, C. (Editors). (2003). Handbook of Mixed Methods in Social \& Behavioral Research. California: Sage Publications, International Educational and Professional Publisher.

Tashakkori, A. \& Teddlie, C. (2010). Mixed Methodology: Combining Qualitative and Quantitative Approaches (Mixed Methodology: Mengombinasikan Pendekatan Kualitatif dan Kuantitatif). Alih Bahasa Budi Puspa Priadi. Yogyakarta: Pustaka Pelajar. 
Tim Kreatif LKM UNJ-Jogjakarta. (2011). Restorasi Pendidikan Indonesia: Menuju Masyarakat Terdidik Berbasis Budaya. Jogjakarta: Ar-Ruzz Media.

Umar Tirtarahardja dan La Sulo, S.L. (2005). Pengantar Pendidikan. Jakarta: Diterbitkan atas Kerjasama Pusat Perbukuan Depdiknas dengan Penerbit Rineka Cipta.

Virtue, D. C.\&Vogler, K. E. (2008). The Pedagogical Value of Folk Literature as a Cultural Resource for Social Studies Instruction: An Analysis of Folktales from Denmark. Journal of Social Studies Research. 32.1 (Spring 2008): 28-39.

Warsito. (2012). Pendidikan Pancasila Era Reformasi. Yogyakarta: Penerbit Ombak.

Warsito dan Asrowi. (2017). Effectiveness of Social Science Learning Based on Noble Values of Ki Hajar Dewantara's Teaching to Strengthen the Students' Character. International Journal of Active Learning. Vol. 2 No. 1, April. 2017. (1-14), p-ISSN 2528-505X, http: //aseanjournals.co 